\title{
"The Secret to a Successful Farm Organization": Township Farm Bureau Women's Clubs in Iowa, 1945-1970
}

\author{
JENNY BARKER DEVINE
}

IN 1945 Nell M. Forsyth of Muscatine County, Iowa, penned the 25-year history of the Cedar Valley Community Club, a township homemakers club affiliated with the Iowa Farm Bureau Federation and the Iowa State Cooperative Extension Service. Forsyth, a founding member of the local club, lauded the efforts of state IFBF leaders and county home economists, but noted that after more than two decades, seasoned club members had tired of uninspired Extension projects that produced "cheese that soon molded, hats that were never worn, and concocted meals that the hired help would never eat." By 1945, club members saw themselves as community leaders who could "help solve some of the most perplexing questions, both local and national." The women of Cedar Valley "needed no outside speaker to construct an interesting meeting" and no longer required direct guidance from state leaders. Forsyth concluded, "'Growing up' is as natural a process for a Club as well as an individual."

1. Nell M. Forsyth, "Cedar Valley Club History," June 1945, Cedar Valley Community Club Records, Iowa Women's Archives, University of Iowa Libraries, Iowa City (hereafter cited as IWA).

I would like to thank the State Historical Society of Iowa for its generous support in the research and writing of this article.

THE ANNALS OF IOWA 69 (Fall 2010). (C) The State Historical Society of Iowa, 2010. 
The story of the Cedar Valley Community Club would have been familiar to farm women across Iowa; those who had joined home demonstration clubs in the 1920s as young homemakers had matured into veteran clubwomen by the 1940s. During and immediately after World War II, farm families enjoyed unprecedented economic prosperity, Farm Bureau membership reached record numbers, and women's clubs thrived. After nearly three decades of strong state-centered programming through the ninemember Iowa Farm Bureau Federation's Women's Committee (IFBFWC), however, club activities in the postwar period were characterized by a greater focus on local leadership. The IFBFWC supported this trend, as shifting rural demographics required new, more flexible programs to address the evolving needs of farm families, and the Farm Bureau ended its official association with the Extension Service. Nonetheless, state leaders maintained high standards and advised local clubwomen to engage in activities related to politics, agricultural policy, safety, rural health, law and order, international relations, and the preservation of democracy. In 1958 the IFBFWC declared that women's clubs had moved beyond simple home demonstration activities, graduating from "'chief cook and bottle washer' status into full fledged study and action groups which tackle problems ranging from world trade to school finance." ${ }^{2}$

Yet, rather than conforming to the ideals of state leaders, members of township Farm Bureau women's clubs became increasingly selective, focusing almost entirely on their neighborhoods, social events, and new trends in homemaking. This is not an indicator of resistance to or rejection of IFBFWC programs but rather the manifestation of social feminisms in the countryside. Social feminisms initially emerged during the Progressive Era and allowed women to politicize their domestic and maternal roles in female-led political organizations. Beginning in the 1910s, state IFBFWC leaders readily applied this rhetoric when organizing women's groups. By the 1950s, local women's choices clearly demonstrated that they had tailored social feminisms to their unique situations. Because of their non-threatening character, social feminisms proved highly adaptable for both rural and

2. "No Problem too Big for Women in the IFBF," Iowa Farm Bureau Spokesman (hereafter cited as IFB Spokesman) 24 (1/4/1958), 2 A. 
urban women from a variety of occupational and social backgrounds, as they addressed issues ranging from suffrage to child labor to the need for good roads. Use of the plural "feminisms" recognizes this flexibility and diversity of social and political activities. In the case of farm women, social feminisms allowed women to draw from agrarian ideals that venerated agricultural producers as honest, hard-working citizens, and to identify their daily labor as inherently political.

For active female Farm Bureau members with years of experience, membership not only provided an indicator of social status and power within a community, but it also allowed some degree of personal empowerment and independence. Members believed themselves qualified to identify appropriate activities, even if their programs deviated significantly from those carefully designed by state and county leaders. Members of township clubs readily adopted the rhetoric of the IFBFWC that identified women as sophisticated activists whose clubs were essential to the overall mission of the Farm Bureau, although they typically viewed club meetings as opportunities for leisure and respite from their daily labors. Membership and leadership roles in local clubs were often fluid and flexible, reflecting gendered divisions of labor, shared work, and women's idealized roles as homemakers. In the immediate postwar period, when technology drastically changed the nature of agricultural production and rural depopulation reduced their overall numbers, township clubs connected women to larger county, state, and national networks and offered women spaces in which to cope with changes in agriculture and rural life.

FOUNDED IN 1919, the Iowa Farm Bureau Federation (IFBF) employed principles of strong central leadership when it consolidated the existing county farm bureaus into the largest, most politically influential farm organization in the state. At the county and township levels, Farm Bureaus provided partial funding for Extension programs and adult education. The IFBF was a "family organization" that upheld gendered divisions of labor, but both male and female leaders at the state level validated women's participation by reasoning that improving conditions in the 


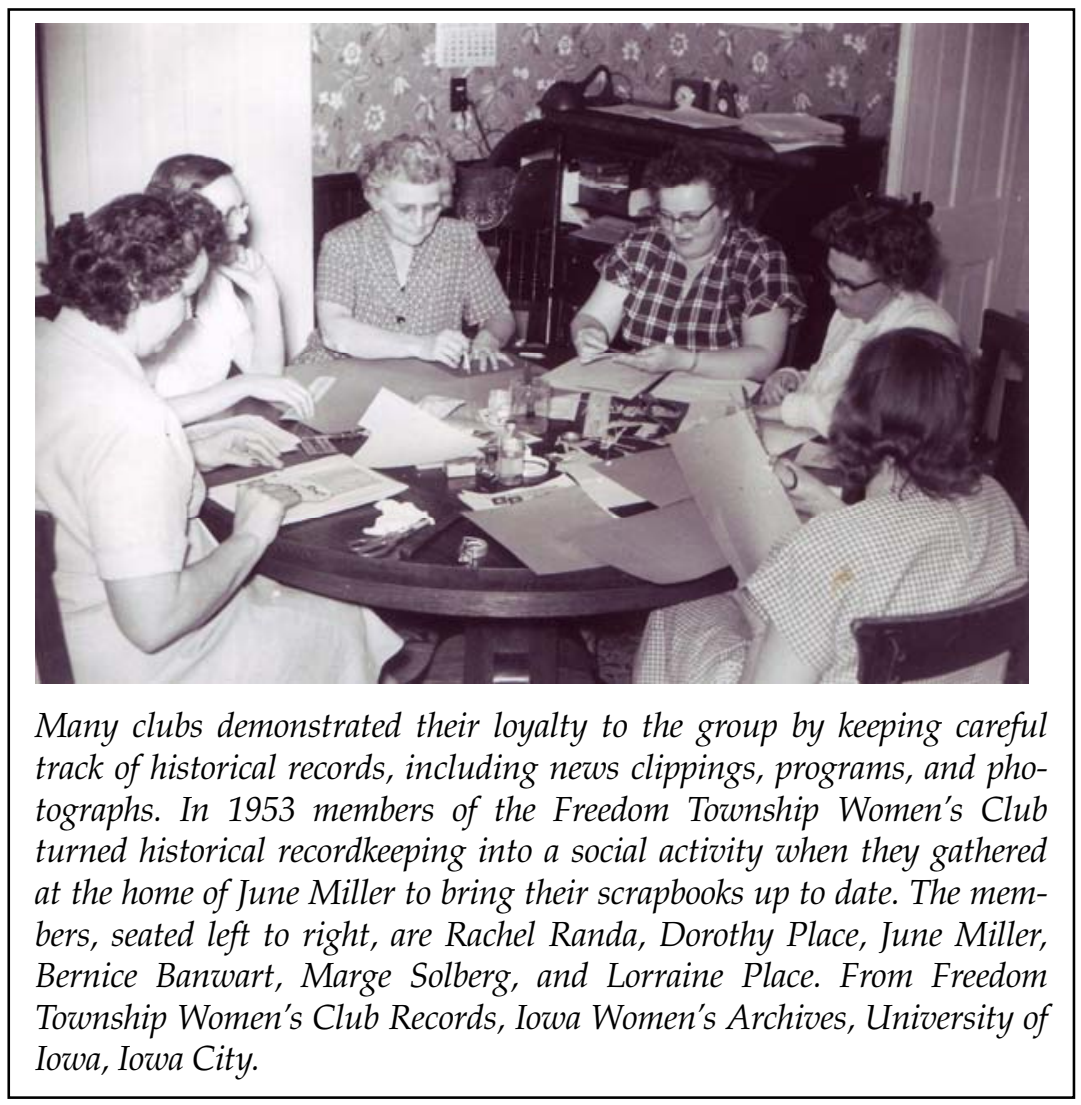

countryside required the efforts of farm women. The IFBFWC, established in 1922 to oversee Farm Bureau women's clubs across the state, spent nearly 30 years empowering farm women to become involved in the greater organization. State leaders presented home economics as the pathway to women's education, community activism, and political participation. Sarah Elizabeth Richardson, a farm woman from Mahaska County, Iowa, and IFBFWC chairperson from 1922 until 1937, introduced elements of the broader, largely urban women's club movement into rural women's organizations by creating a hierarchy of leadership for women at the state, district, county, and township levels. She insisted that women's clubs were not auxiliaries but rather equal components within the IFBF, and required local clubs to recog- 
nize the gravity of their work by conforming to rigid rules for leadership, recordkeeping, regulations, and programming. ${ }^{3}$

During World War II, however, Richardson's system became increasingly difficult to maintain as rationing and shortages prevented state leaders and Extension personnel from holding state conferences to share their plans for the coming year. They asked county and township leaders to develop and oversee their own programming. In 1944, for the first time in its 22-year history, the Mahaska County Farm Bureau Women's Committee allowed women in township clubs to select their own activities and recorded in its history that "developing leadership, [and] how to form policies and resolutions in the townships were beginning to be a part of the women's program." The women of Mahaska County hoped that this move would allow women to better address the "problems facing the farm people in the post war years," including economic security, roads, health, modern equipment, electricity, and rural schools. Much of the old system developed under Richardson's leadership remained intact, and following the war IFBFWC leaders sought balance between the local control desired by members of township clubs and the new ideals that the IFBFWC wanted farm women to achieve. ${ }^{4}$

The extent to which centralized state leadership affected the perceptions of women who joined township women's clubs has been at the center of scholarly debate for the past two decades. The hierarchical nature of the Farm Bureau suggests that state leaders, informed by middle-class Progressive Era ideals, exerted considerable control over the dissemination and application of information at the local level and that desires for local control might have been a manifestation of women's resistance. Historian Katherine Jellison asserts that because state and federal officials designed Extension programs that clearly defined farming as a male occupation, they devalued women's roles as agricul-

3. Dorothy Schwieder, 75 Years of Service: Cooperative Extension in Iowa (Ames, 1993), 20-22, 34-37; Jenny Barker Devine, "'Quite a Ripple but No Revolution': The Changing Roles of Women in the Iowa Farm Bureau Federation, 19211951," Annals of Iowa 64 (2005), 1-3.

4. Devine, "'Quite a Ripple but No Revolution,'” 26; Josephine Van Zomeren, "Mahaska County Farm Bureau Women," December 1971, Mahaska County Farm Bureau Women's Committee Records, IWA. 
tural laborers. By focusing on home economics and pressuring women to behave as consumers, state and federal leaders unleashed an "onslaught of propaganda attempting to make women relinquish their role as farm producer." Similarly, historian Mary Neth argued that between 1920 and 1940, as state Farm Bureau and Extension leaders consolidated their power, they imposed middle-class, urban ideals on farm women that removed them from agricultural production as well as the business and politics associated with farming. Although homemakers clubs "never lost their local character," Neth concluded that by 1940, Farm Bureau clubs had undermined women's "traditionally active role in community groups and diminished the power they exerted in . . encouraging neighborhood loyalty." ${ }^{5}$

When viewed from the local perspective, however, a very different story emerges. Historian LuAnn Jones found that at the grassroots, "government-sponsored rural reform assumed a more contested and less cohesive character." State leaders created centralized leadership networks, but local clubs ultimately determined the success or failure of programs. Women who joined township clubs expressed a sense of empowerment when selecting activities that fit their unique interests. Women did not join the Farm Bureau on an equal footing with men, but historian Nancy K. Berlage still found that local clubs offered women "access to new forms of cultural and political authority." Although Berlage wrote about the 1920s, the idea that all-female clubs were appropriate political outlets for women persisted throughout the twentieth century. In 1947, for example, Ardath Gasser, chairperson of the Howard County Farm Bureau Women, wrote that women needed to work with men and "offer more help" with IFBF legislative programs, but she did not expect women to entirely abandon their clubs. Instead, she wrote, "the township meeting is the secret to a successful farm organization," and she encouraged more women to attend women's county leadership workshops. Likewise, in 1954 chairperson Christine Inman stated that the IFBFWC should build from the "township

5. Katherine Jellison, Entitled to Power: Farm Women and Technology, 1913-1963 (Chapel Hill, NC, 1993), xxi; Mary Neth, Preserving the Family Farm: Women, Community, and the Foundations of Agribusiness in the Midwest, 1900-1940 (Baltimore, 1995), 137-39. 
level and up." Because national policies often originated as discussions in local clubs, the strength of the organization depended "upon the strength of our township Farm Bureaus." Inman described township chairpersons as foundational leaders with the power to set policies and propose IFBF resolutions on a wide variety of issues. ${ }^{6}$

To secure local leadership, the IFBFWC legitimated women's activities in public spaces by focusing on domestic and community responsibilities as well as their partnerships with men and their own deep connections to agriculture. Acknowledging their dependence upon men for access to land and resources was an important component of rural women's activism because a woman's ability to negotiate power within a family depended not on the economic, social, or political value of her work but entirely on her husband's notion of proper gender roles. Stepping outside of those roles might cause embarrassment for the family or frustrations at home when a woman made club work a priority. Such rhetoric remained central to the IFBWC as late as 1966, when Edna Garrels, chairperson of the Pocahontas County Farm Bureau Women's Committee, wrote, "The moral and religious tone of the nation is set in our homes. . . . This, then, is our first and probably our most important role, to set the moral and religious values of our nation." Garrels reasoned that because of their roles as the moral custodians of society, women needed to be involved with family spending decisions, farm management, business, marketing, the IFBF, and politics. ${ }^{7}$

6. LuAnn Jones, Mama Learned Us to Work: Farm Women in the New South (Chapel Hill, NC, 2002), 24, 38; Nancy K. Berlage, “Organizing the Farm Bureau: Family, Community, and Professionals, 1914-1928," Agricultural History 75 (2001), 426-28; "Township Meeting is Emphasized by Howard County Woman," Official Bulletin of the Iowa Farm Bureau Federation (August 1947), 5; Christine Inman, "Strength of Structure Depends on Foundation," IFB Spokesman 22 (5/29/1954), 12.

7. Monda Halpern, And On That Farm He Had a Wife: Ontario Farm Women and Feminism, 1900-1970 (Montreal and Kingston, 2002), 6-8; Mary Neth, "Building the Base: Farm Women and the Rural Community and Farm Organizations in the Midwest, 1900-1940," in Women and Farming: Changing Roles, Changing Structures, ed. Wava G. Haney and Jane B. Knowles (Boulder, CO, 1988), 339-55; Neth, Preserving the Family Farm, 137-39; Edna (Mrs. Otto) Garrels, "Role of Farmer's Wife Becomes More Important," IFB Spokesman 34 (9/9/1966), 12. 
Historian Monda Halpern identifies this ideology as "social feminism," which utilized domestic and maternal discourses that encouraged women to organize separately in all-female spaces where they could exercise authority and develop leadership skills without the interference of men. The roots of social feminisms can be traced to women's movements of the late nineteenth and early twentieth century, but such rhetoric maintained its power well after World War II and appeared in both urban and rural settings. In her study of the National Federation of Republican Women, for example, historian Catherine Rymph found that after 1945, women increasingly focused on the "day-to-day work that received little glory but was critical to sustaining and building the party." Rather than questioning male leaders who often disregarded female participation, Republican women made themselves indispensable by feminizing such tasks as canvassing, voter registration, and organizing small-scale political events. By emphasizing domesticity, "hospitality and neighborliness," Republican women connected "partisan politics to the everyday lives of citizens in their communities." Similarly, members of Farm Bureau women's clubs asserted that activism could take place while carrying out one's daily activities. In 1954, while organizing a membership drive in Palo Alto County, county publicity chairperson Olga Rouse informed members that they did not need to go door to door or talk with unknown persons but rather "create interest in the organization by personal contact with their neighbors. We can invite our neighbor women to meetings and Farm Bureau activities. We can talk to them about the advantages of belonging.."

The empowering nature of social feminisms can be difficult to detect, especially in the rural context, because women celebrated feminine ideals and rarely challenged men's authority.

8. Halpern, And On That Farm He Had a Wife, 76-78; Louise I. Carbert, Agrarian Feminism: The Politics of Ontario Farm Women (Toronto, 1995), 27-28; Susan Lynn, "Gender and Progressive Politics: A Bridge to Social Activism of the 1960s," in Not June Cleaver: Women and Gender in Postwar America, 1945-1960, ed. Joanne Meyerowitz (Philadelphia, 1994), 104; Catherine E. Rymph, Republican Women: Feminism and Conservatism from Suffrage through the Rise of the New Right (Chapel Hill, NC, 2006), 133, 137-38; Olga Rouse, "Contact Meeting Held by Farm Bureau Women," undated news clipping in Scrapbook, 1954, Freedom Township Women's Club Records, IWA. 
The strength and persistence of farm women's clubs, however, clearly demonstrate the pervasiveness of social feminisms and their appeal to local club members. Conceptions of women as activists and vital Farm Bureau members were not limited to state leaders. By the late 1940s, social feminisms clearly informed members of Farm Bureau township women's clubs who desired greater local control over club activities.

In 1948, when the women of Freedom Township in Palo Alto County celebrated their club's twenty-fifth anniversary, they wrote and performed a play that not only recounted key developments in the club's history but concluded by looking forward to a bright future in which the women of Freedom Township would find "new paths of usefulness, not only in her community, but in her county, her country, and her world." Their future development depended not on challenging patriarchy or seeking the integration of women into the IFBF but in continuing to develop leadership in an all-female club. ${ }^{9}$

SOCIAL FEMINISMS provided the language and context for women to assert their preferences at the local level, but changing rural demographics after 1945, as well as new policies within the IFBF and the Extension Service, also necessitated alternative strategies in rural women's activism. Maintaining rural communities wherein women shared work, friendship, and common ideals became especially important in the postwar period as more families moved away from the farm and informal neighborhood networks became less stable. Between 1950 and 1970, the average farm size in Iowa increased from 160 acres to nearly 250 acres, while the number of farms declined from 107,183 to 72,257. In 1950, 30 percent of Iowans lived on farms, but by 1960 that number had dropped to 24 percent, and by 1970 it had fallen to 18 percent. By 1980, just 13.4 percent of Iowans lived on farms.

9. Laura Schroeder, "A History of The Swastika Club," in Scrapbook, 1948, Freedom Township Women's Club Records, IWA; Christine Inman, "Strength of Structure Depends on Foundation," IFB Spokesman 22 (5/29/1954), 12. When the women of Freedom Township formed their organization in 1923, they selected the name "Swastika Club." The swastika, an ancient emblem, comprised four "Ls," which had come to represent "luck, light, love, and light." In 1942, following U.S. entry into World War II, members voted to change the name of their club to the Freedom Township Women's Club. 
Rural depopulation was a nationwide trend, but these changes were especially unsettling in states that depended on their agricultural productivity. ${ }^{10}$

Furthermore, technological and social changes meant that by the 1950s farm women lived in a vastly different world than that of their predecessors of the 1920s. In 1950, 90 percent of Iowa farms had electricity compared to 21 percent in 1930. Electricity allowed farm families to invest in household equipment: by 1960, 87 percent of Iowa farm homes had piped water, 96 percent a washing machine, 64 percent a freezer, 91 percent a telephone, and 91 percent a television. Moreover, declining prices for food and consumer goods made it more cost effective for women to purchase, rather than make, what they needed for their families. Modern conveniences and consumption of consumer goods required women to acquire new homemaking techniques, learn about agribusiness, or possibly earn cash income. More women took over the business aspects of their family farming operations, while in 1960 nearly 20 percent of farm women over 14 years of age held jobs off the farm, compared to 13 percent in 1950. As their labor evolved, fewer young women chose to become involved in homemakers clubs, often citing interest in other activities or a lack of time. By 1957, one national survey of Extension clubwomen found that only 11 percent of the 11,500 women surveyed were under the age of 30 . The majority of Extension clubwomen across the nation (51 percent) were between 30 and 49; the remaining 38 percent were over the age of $50 .^{11}$

Income level and social class are two factors that, unfortunately, cannot be easily measured as contributing factors to the shift toward local leadership. Some scholars have suggested that Farm Bureau members tended to come from more prosperous farms and perhaps preferred exclusive membership, but not

10. U.S. Department of Agriculture, Agricultural Statistics: 1967 (Washington, DC, 1967), 443, 573; Willis Goudy et al., Rural/Urban Transitions in Iowa (Ames, 1996), 59, 82; Margaret Hanson et al., Agriculture in Iowa: Trends from 1935 to 1997 (Ames, 1999), 29.

11. U.S. Bureau of the Census, 1960 Census of Housing (Washington, DC, 1963); Jellison, Entitled to Power, 155, 174; Jewell G. Fessenden, "These Are the Women Who Are Members of Home Demonstration Organizations in the United States: A Report from a National Study of Home Demonstration Members," Extension Circular 528 (Washington, DC, 1958), 2-5. 
enough data has been compiled to draw broad, definitive conclusions. In her study of the American Farm Bureau Federation, historian Nancy K. Berlage hesitates to make "reductionist assumptions" about the economic backgrounds of Farm Bureau members, noting that "county membership lists are often incomplete or non-existent." There is evidence, however, to suggest that women involved in the Farm Bureau and Extension programs in the postwar period aspired to standards of living akin to those of urban and suburban middle-class families. In 1955 Marshall County home economist Greta W. Bowers reported a rapid growth in the number of families with conveniences such as freezers, televisions, decorative fireplaces, and musical instruments. Bowers also found that as rural homes became "increasingly more modern," more women demanded lessons on contemporary interior design and the selection of "accessories that add beauty." She predicted that as farm families came to enjoy more material comforts, rural women, like their urban counterparts, would have "more time to devote to her church and other civic affairs." Middle-class aspirations are further reflected in the photographs pasted into the scrapbooks of the Freedom Township Women's Club, in Palo Alto County, which reveal that by the late 1940s, women attended meetings with professionally styled hair and wearing fashionable dresses, with newly remodeled homes as their backdrop. Their meetings were clearly opportunities to engage in leisure activities and exhibit their tastes as consumers, and may have limited membership to those with the means to participate. ${ }^{12}$

The records of the IFBFWC, as well as those of township clubs, are silent on the issue of social class and economic difference. Instead, age was their primary concern. Township clubs celebrated founding members and the fact that their club might include second- or even third-generation members, but the overall increasing age of club members arose as a concern more often than any other factor when discussing programming changes, the recruitment of new members, and, by the late 1960s, rea-

12. Neth, Preserving the Family Farm, 134-35; Deborah Fink, Open Country Iowa: Rural Women, Tradition, and Change (Albany, NY, 1986), 217; Berlage, "Organizing the Farm Bureau," 408; Fessenden, "These Are the Women," 2-3; Scrapbooks (1923-1967), Freedom Township Women's Club, IWA. 
sons for declining membership. The Extension Service and the IFBFWC began to recognize the diverse needs of individuals at varied life stages in an age of rapid modernization. As they adapted programs to help rural residents adjust to depopulation, mechanization, electrification, and the rising costs of agricultural production, they also acknowledged that women often worked as farm laborers and bookkeepers. The Extension Service began offering instruction through the Farm and Home Development program designed to help married couples make decisions about production, implements, and marketing. Beginning in the 1940s, the IFBF also designed programs for "young marrieds" in which couples under 30 addressed such issues as land ownership versus tenancy, buying and leasing machinery, organizational participation, the importance of rural communities, and off-farm work. The IFBFWC strongly supported women's participation in groups for "young marrieds," hoping that the younger women would later become involved in women's clubs. Unfortunately, this expectation did not materialize, and by the late 1960s membership numbers declined rapidly. ${ }^{13}$

IN ADDITION to the evolving needs of farm families, the major organizational change that led the IFBFWC to focus on local developments occurred in 1954, when state and federal policy ordered the Extension Service to end its relationship with the Farm Bureau. By 1951, the IFBF provided more than 34 percent of the annual budget for Extension, which seemed to many politicians and policy makers a conflict of interest given the Farm Bureau's intense political activity. As a result of the separation, county and township clubwomen could no longer rely on the assistance of Extension home economists for planning activities. For example, the women of Freedom Township, in Palo Alto County, depended on their county home economist, Signora McFadden, to occasionally attend meetings and give lessons,

13. Dorothy Schwieder, "Cooperative Extension and Rural Iowa: Agricultural Adjustment in the 1950s," Annals of Iowa 51 (1992), 610-13; Summer Conference Booklet, Iowa Farm Bureau Women's Committee Summer Conference (1970), IFBFWC Records, Special Collections, Iowa State University Library, Ames; "Young People Farm Because They Like It; Join Farm Groups to Have Stronger Voice," IFB Spokesman 36 (10/18/1969), 13. 
bring members up to date about Farm Bureau and Extension programs, and provide informational materials for the next year's work. Each month, McFadden also sent postcards to remind members about upcoming meetings and provided announcements to local newspapers. McFadden ended those practices in 1955, requiring the township club to assume responsibility for planning, procuring Farm Bureau materials from the state and county offices, and generating publicity. County Farm Bureaus throughout the state continued informal relationships with Extension personnel, but in a speech at the 1955 state conference, IFBFWC chairperson Christine Inman urged county and township clubs to cultivate new Farm Bureau leaders. In light of the separation, she said, "We have a tremendous responsibility to make policy and to carry it out. We need leadership. We must develop people dedicated to carrying out our plans."

Over the next several years, the Iowa Farm Bureau Spokesman featured articles that lauded the efforts of county and township women's clubs to carry on despite the absence of county home economists. Intended to inspire members of women's clubs, one 1957 article told the story of Buchanan County, which lost its county home economist in August 1956. As the most experienced female leaders in the county, Farm Bureau women instituted their own programs under the guidance of the county women's committee chairperson. Working with women in 12 townships, Farm Bureau women oversaw the completion of more than 300 projects, including copper embossing, Swedish embroidery, home landscaping, and even a survey of rural mail delivery routes. The IFBFWC clearly expected women to assess the needs of families in the county and organize activities accordingly, though such expectations could prove frustrating in counties that maintained Extension home economists. In her

\footnotetext{
14. Memorandum: "Funds Expended in 1951 for County Extension Program," IFBF Records, Special Collections, Iowa State University Library, Ames; Memorandum: "State Farm Bureau-Extension Relationships," 1950, IFBF Records; E. Howard Hill to County Farm Bureau Presidents, 11/29/1954, IFBF Records; Schwieder, "Cooperative Extension and Rural Iowa," 606; Schweider, 75 Years of Service, 196; Scrapbooks (1954-1955), Freedom Township Women's Club, IWA; Mrs. I. J. Bulyer, Cherokee County, "Looking Both Ways," The Summer Echo (newsletter published during the IFBFWC Summer Conferences), 6/27/1955, Irene Hoover Papers, IWA.
} 
1959 annual report, Linn County home economist Grace B. Drenkhahn chronicled her efforts to organize "cooperative organizational teas" for women on Extension's Family Living Committee and the county Farm Bureau Women's Committee. Yet Drenkhahn found that the Farm Bureau women simply assumed responsibility for planning the program, often subordinating the desires of the Family Living Committee. ${ }^{15}$

State IFBFWC leaders and local leaders at the county and township level agreed on the necessity for strong local leadership, but their visions for how this would take shape differed significantly. Concerned about the declining numbers of young farm women in their clubs, county and township leaders asked for more programs "directed to helping families acquire mental rather than physical or manual skills." Younger farm women were better educated, more likely to have urban backgrounds, and more likely to have had formal training in home economics. Similarly, seasoned members with honed domestic skills, whose children were either in school or out of the home, sought activities that offered intellectual and social respite from the constant demands of farming. In response, the IFBFWC encouraged women to develop new interests outside of agricultural production and home economics and to see their township meetings as forums for discussions about politics and social policy. At the 1952 IFBFWC Summer Conference, Marie Garnjobst, the third district committeeperson from Clay County, spoke about the need to alter existing programs and told county leaders, "We must evaluate activities and determine whether or not the program helps our women to become more intelligent, more effective, and more responsible as citizens." Good leaders who "sought progress" at the county level, Garnjobst stated, were those who encouraged women to adopt the state plans and asked women to think beyond the farm and home. ${ }^{16}$

15. "Buchanan County Farm Bureau Women Have Lively Program," IFB Spokesman 23 (4/6/1957), 13; "Linn County," Annual Narrative Reports of County Extension Agents (Ames, 1959), 26.

16. Jellison, Entitled to Power, 170-75; Fessenden, "These Are the Women," 2-5; "Farm Bureau's 10-Point Program for Agricultural Prosperity" (1953), IFBF Records; The Summer Echo, 6/10/1952, Irene Hoover Papers, IWA. 
The IFBFWC sought to ensure that serious discussion of social and political issues took place in local meetings by producing handbooks for local leaders, designing informational courses to be taught at the county level, and encouraging women to use roll calls with political themes such as "Freedoms I would not want to lose." In addition, state leaders required local clubs to appoint chairpersons to study specific issues and then report back to the other members at their monthly meetings. For example, in September 1956, at the first meeting of the Franklin Township Women's Club in O'Brien County, members elected chairpersons to study "Freedom in the United States," "The Promotion of Agricultural Commodities," "Safety on the Farm," "Rural Mail Delivery," "Conservation," "Schools," and "Rural Health." During their one-year term, these women read Extension and Farm Bureau materials on their assigned topics, and they clipped articles from newspapers or magazines to share at meetings. They typically provided enough information for women to become aware of various issues, but not necessarily enough to explore problems in great detail. Studying "International Issues," for example, might include brief lessons about geography, how to start a correspondence with an international pen pal, or a presentation by a local student recently returned from a study abroad experience. For many of the members, though, this was their primary source for news and discussion on these issues. Occasionally, they developed community improvement projects based on what they learned. In 1948 the women of the Freedom Township Women's Club in Palo Alto County studied public health, and then cooperated with other civic and political groups to form the Palo Alto County Health Council. With a member of the women's club at its head, the new Health Council sought a tax levy to support a county health nurse. ${ }^{17}$

In order to measure the success of IFBFWC programs, and to ensure that women effectively used materials distributed by state leaders, townships clubs submitted annual reports and "score sheets." Beginning in the 1950s, the IFBFWC collected township

17. "Secretary's Book, 1956-1957," Franklin Township Women's Club Records, IWA; Fink, Open Country Iowa, 217; Schroeder, "A History of The Swastika Club." 
score sheets at county leadership workshops. Township clubs could earn points in a variety of areas: for members of township clubs who attended county meetings, for the number of meetings held, for providing evidence that "a Farm Bureau lesson or emphasis was presented at each township meeting," for having their photographs published in the Iowa Farm Bureau Spokesman, for donating to the Farm Bureau teacher scholarship fund, for having chairpersons to cover various issues, and for their unique township and county activities. Total scores were pitted against those of other township clubs, and clubs with high scores were recognized at the annual conferences. County leaders were also required to host annual events, such as Rural Women's Day or Family Night, where township clubs showcased their work through displays, skits, and presentations. ${ }^{18}$

In addition to publications, forms, and events, state leaders also provided constant encouragement and support for local leaders. At the 1952 IFBFWC Summer Conference, when state leaders selected annual programs, the ninth district committeeperson urged county leaders to raise standards for Rural Women's Day by focusing more on the quality of the projects and presentations and less on the social aspects of the event. She said, "Rural Women's Day is a time to show appreciation for the leaders and workers who have contributed to this program throughout the year - but, we should not spend all day pinning on corsages." "Rural Women's Day," she added, needed to provide "a clear picture of the year's work in Extension Education and Farm Bureau programs" so that state leaders could evaluate the effectiveness of their efforts. ${ }^{19}$

IFBFWC LEADERS balanced this concrete advice with more abstract promises of personal and intellectual fulfillment. By engaging in their programs, township women could become "modern" farm women who not only worked to improve agriculture but who also embraced the urban ideals of consumer-

18. "Score Sheet for Rural Women's Clubs," for Freedom Township (1954), Freedom Township Women's Club Records, IWA; "Farm Bureau Women's Township Report and Score Sheet," for Westburg Township (9/29/1971), Anita Crawford Papers, IWA.

19. The Summer Echo, 6/10/1952, Irene Hoover Papers, IWA. 
ism, femininity, and leisure. Club membership no longer helped women learn to "make do" with less, as it had in an earlier period, but was rather an indicator of leisure time and of one's place in the new affluent society. As clubwomen's desire for leisure activities and modern conveniences grew, comments about personal appearance, clothing, and style appeared regularly on the women's page of the Spokesman, with advice on how to follow the latest trends. Whereas former IFBFWC chairperson Ruth Sayre, who served during the 1930s and 1940s, had been revered for her economical clothing and worn winter coat, in 1961 IFBFWC chairperson Alice Van Wert declared, "The American farm wife today is as hat-conscious and familiar with the latest in hair-dos and clothes as any woman in the city." In other words, farm women could move away from iconic images of farmers' wives as provincial drudges and instead present themselves as sophisticated women. ${ }^{20}$

Generally, women in county and township clubs responded to the IFBFWC's rhetoric and attempted to integrate more discussions about agricultural activism, politics, and social policy into their programs. Letters from women to the editor of the Iowa Farm Bureau Spokesman demonstrate that they were very aware of the political and social issues facing rural America, and they wanted to be part of the solution. Throughout the 1950s and 1960s, however, the IFBFWC provided little financial or logistical support for township clubs to actually apply information as community activists. For example, the IFBFWC encouraged women to study commodity promotion in order to understand agricultural markets. Yet rather than studying how to organize promotional activities in urban areas to educate consumers, township clubs primarily promoted commodities to themselves and other farm families. In 1958 the Freedom Township Women's Club in Palo Alto County translated commodity promotion into the distribution to club members of paper napkins from the local Mallard Creamery that "pictured and encouraged the use of meat, milk, butter, and eggs in the home." They also studied pamphlets printed by the Iowa State Dairy Commission and used them to write an article for the Iowa Farm

20. Julie McDonald, Ruth Buxton Sayre: First Lady of the Farm (Ames, 1980) 59; "Farm Wives Chic-to-Chic ... ," IFB Spokesman 27 (3/18/1961), 4. 
Bureau Spokesman that pointed "out the highly beneficial qualities of animal proteins in the daily consumption of these products." Likewise, in March 1960 the Highland Do-Better Club in O'Brien County joined a local pork producers association in a Lard Promotion Day. The women sponsored a "Bake It with Lard" contest, hoping to raise some money from the sale of winning entries. Yet the contestants, judges, and spectators were all from the local farming community and likely already understood the importance of effective marketing. ${ }^{21}$

Women in township clubs preferred community activities that offered tangible results and that did not require them to challenge established conventions in their rural communities pertaining to politics and gender. In the fall of 1952, when confronted with rural school consolidation, the women of Freedom Township in Palo Alto County became concerned that when the township school closed, residents would be left without a central meeting area or a place to vote in local elections. They established a committee to look into the issue, but rather than pursuing the matter through official political channels, they began informal discussions with neighborhood landowners and members of the school board to secure use of the facility. In April 1953 they purchased the building and declared the school to be "ours." They began budgeting for property taxes and physical improvements. Throughout the summer, they painted the walls, sewed curtains, and installed an electric stove, using volunteer labor and donated materials. Over the next decade, they held their monthly meetings, as well as special events, pancake suppers, and 4-H recognition days, at their Freedom Township Hall. They fulfilled a need in the community by preserving a local meeting place, but did so with the help of familiar residents and local resources. ${ }^{22}$

21. Unattributed news clippings dated September 1958 and 9/22/1959 in Scrapbooks, 1958-1959, Freedom Township Women's Club Records, IWA; Meeting Minutes, 3/7/1960, Highland Do-Better Club Records, IWA. Letters from Iowa farm women appeared regularly in the IFB Spokesman, most often offering responses to articles regarding agricultural production and politics. See, for example, Mrs. L. Gustafson to editor, IFB Spokesman 22 (3/24/1956), 4; Mrs. Horace Thee to editor, IFB Spokesman 23 (10/13/1956), 4; IFB Spokesman 36 (5/30/1970), 4. 22. Meeting Minutes, October 1952-June 1953, Freedom Township Women's Club Records, IWA. 


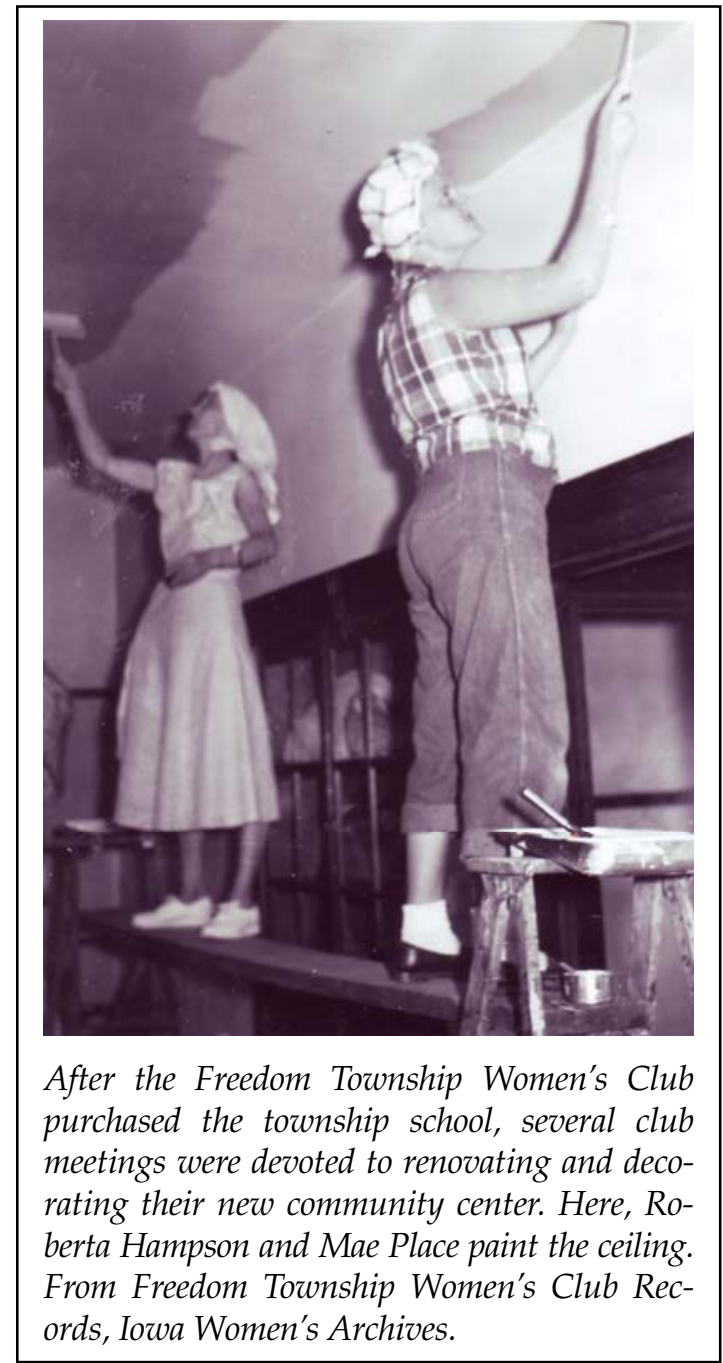

When planning monthly meetings, most township clubs preferred inexpensive activities that required minimal planning and combined practical advice with opportunities for social interaction. That allowed club members to express personal preferences and desires to maintain a strong club, because women would only attend meetings that seemed relevant to their daily lives. Historian Mary Neth argued that Farm Bureaus in midwestern states tended to have "less active participation, less so- 
cial attachment, and less commitment from farmers than other groups" and that membership did not necessarily imply a "full acceptance of [the Farm Bureau's] agricultural policies." Attendance records from the late 1950s and early 1960s support this conclusion and reveal that most women did not attend meetings on a regular basis. For example, between October 1959 and June 1960, of the 21 members listed on the roll for the Franklin Township Women's Club in O'Brien County, only one had perfect attendance; ten missed between three and five meetings, and seven missed more than six meetings. The women who tended to miss meetings, however, participated in major events such as potluck suppers, "Achievement Days," and community events. Franklin Township was not unique; similar patterns appeared consistently in membership rolls for several townships, suggesting that women's membership allowed them to remain connected to the local community and to friends rather than serving as an expression of loyalty to the IFBF. ${ }^{23}$

IFBFWC LEADERS understood that local planning was essential to secure and keep members, but even with score sheets and clearly written handbooks, they could not control the activities and projects selected by township clubs. Deviations from state and even county plans were common and are evident in the 1959 state, county, and township handbooks used by the women of Freedom Township in Palo Alto County. The 1959 IFBFWC handbook outlined discussion subjects such as legislation, conservation and water rights, commodities, world trade, and marketing, and included an introduction from the state chairpersons that advised, "The finest program of work and the most comprehensive reference book are of no value unless they are used." In contrast, the Palo Alto County Farm Bureau Women's Committee provided handbooks to each township that only required clubs to hold meetings with informational sessions on

23. Neth, Preserving the Family Farm, 134-35; Membership Roll, October 1959 to June 1960, Franklin Township Women's Club Records, IWA. See also Secretary's Books and Membership Rolls, 1959-1970, Franklin Township Women's Clubs Records, IWA; Membership Roll, December 1959 to December 1960, Highland Do-Better Club Records, IWA; Membership Roll, December 1960 to December 1961, Sharon Township Women's Club Records, IWA. 
nutrition, cooking methods, and first aid. Handwritten notes in the county handbook reveal that when the Freedom Township Women's Club held the meeting devoted to first aid, it entailed only a brief presentation. The meeting was actually an all-day event featuring a covered-dish luncheon with a plan to "do fancy work during the day." Plans for other meetings that year allowed for short presentations by the chairpersons elected to study various issues but typically focused more on social activities. Club members shared book reviews, remodeled their Township Hall, planned a township family picnic, hosted a Mother's Day Tea, held "Achievement Days" for boys' and girls' 4-H clubs, organized a family Christmas party, and studied such topics as table settings, gift wrapping, and "Iowa." ${ }^{24}$

The women of Freedom Township demonstrated an awareness of the programs designed by the IFBFWC but deliberately chose not to follow them. In 1960, when the IFBFWC asked county and township women to study civil defense, the cover of the Palo Alto County handbooks featured a pencil sketch of a mushroom cloud, and the Freedom Township Women's Club organized a special civil defense committee. The committee could have easily followed the 12 monthly programs designed by the IFBFWC for local clubs, including "What is Civil Defense Mobilization?" and "What is radioactive fallout and how can we protect ourselves?" The IFBFWC also suggested that members take a Red Cross First Aid Training Course, learn about home fallout shelters, watch films on civil defense, study atomic science, and construct home first aid kits. The IFBFWC handbook provided lists of films and materials that women only needed to send for if they wanted to use them, so that participating in the program would not have incurred major expenses for any club. Yet, other than a short presentation by the club civil defense chairperson at one meeting, the women of Freedom Township had no programs that aligned with the goals of the IFBFWC. In addition to their annual social events, such as the family picnic, 4-H Achievement Day, and the Christmas party, they elected to

24. Iowa Farm Bureau Women's Program, 1, Scrapbook (1959), Freedom Township Women's Club Records, IWA; Palo Alto County Farm Bureau Women's Club Handbook, 1959, Scrapbooks (1959), Freedom Township Women's Club Records, IWA. 


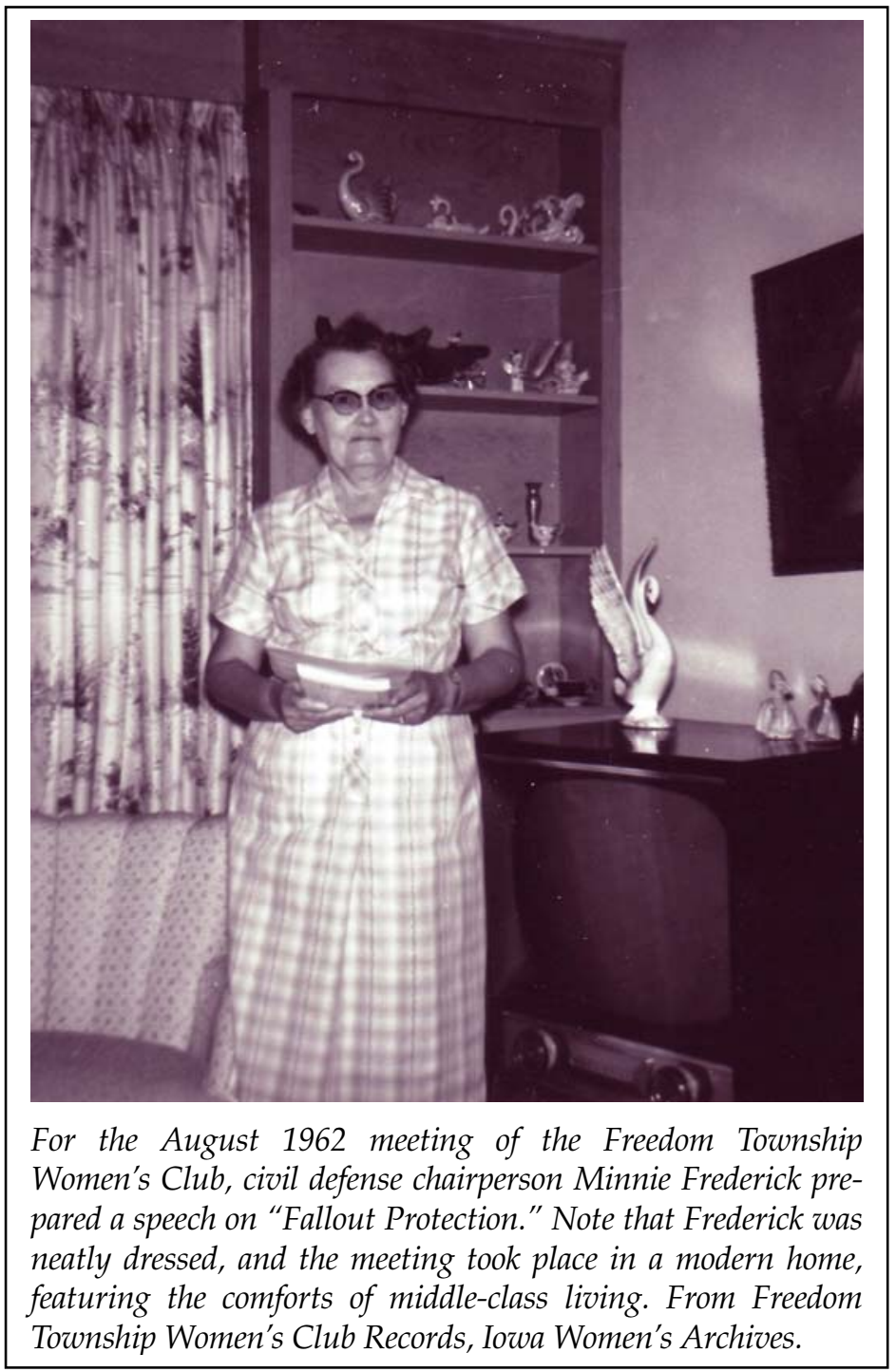

study lessons titled "Ways with Cheese," "Understanding Our Children and Grandchildren," "How to Save Time in the Kitchen," "Laundry Problems," and "Landscaping your Home." ${ }^{25}$

25. Palo Alto County Farm Bureau Women's Club Handbook, Scrapbook, 1960, Freedom Township Women's Club Records, IWA. 
Palo Alto County's remote location in north central Iowa, far from urban centers, might explain why the women of Freedom Township neglected to study civil defense, but so did the women in Scott County, where farm families lived in close proximity to the cities of Davenport, Iowa, and Rock Island, Illinois. Members of the Cleona Township Women's Club in Scott County selected programs such as "Know your retail stores," "Better grooming," and "Figure flattery." They also sewed carpet squares for disabled children, hosted an organizational tea, and, in December, rather than taking a quiz on civil defense as suggested by state leaders, hosted a Christmas party. Only twice did they comply with the state programs: in May 1960 they took a tour of the nearby Rock Island Arsenal to view a mobile hospital, and in October they assembled home first aid kits. Otherwise, the Cleona Township women, like other women's clubs across the state, apparently had few reservations about selecting programs that differed significantly from those recommended by the IFBFWC. ${ }^{26}$

The clubwomen's neglect of state programs did not necessarily represent expressions of resistance to Farm Bureau policies or a rejection of the IFBFWC. For example, the members of the Freedom Township Women's Club demonstrated loyalty to the IFBF in 1948 when they sponsored a year-long membership drive, selling new members on the benefits of Farm Bureau membership and nearly tripling their numbers from 44 to 119 . Throughout the late 1940s and 1950s, they also participated in the annual Rural Women's Day events by providing refreshments, music, entertainment, and informative displays. For several years, even when they did not follow state programs, the Freedom Township Women's Club won awards for its activities at Rural Women's Day, usually for its record of sending women to county leadership training workshops and the number of members elected to IFBF county leadership positions. ${ }^{27}$

26. "1960 Annual Program," Scrapbook, 1960-1974, Cleona Township Women's Club Records, IWA. For more on Iowa communities' responses to civil defense programs sponsored by the Extension Service, see Jenny Barker Devine, "The Farmer and the Atom: The Iowa State Cooperative Extension Service and Rural Civil Defense, 1955-1970," Annals of Iowa 66 (2007), 161-94.

27. "Large Crowd of Palo Alto Farm Women at Annual Program Here," and "Freedom Wins Despite 'Atomic Bombs,', unattributed news clippings in Scrapbook (1948), Freedom Township Women's Club, Records, IWA; "127 at County 
If they disagreed with IFBF policies, or simply found their association to be of little value, women's clubs could end their relationship with the Farm Bureau and Extension and transform their group into one of the many informal women's clubs that existed in rural areas. The Cedar Valley Women's Club did just that in 1946, just one year after it celebrated its twenty-fifth anniversary and declared that it needed no outside help in planning programs. Although the Cedar Valley women did not explain their exact reasoning, they dropped all political discussions from their meetings and withdrew from county Farm Bureau activities. Instead, they discussed books, held contests, sang songs, played games, finished handiwork, and helped the hostess with household chores. The Cedar Valley Community Club continued these activities well into the 1990s, demonstrating that its members not only found value in the group but also had the leadership and organizational skills to maintain an effective club. ${ }^{28}$

Women with no interest in Farm Bureau programs had a variety of options for community participation, including church groups, garden clubs, and other informal clubs. Typical of these informal clubs was the Friendly Neighbors Club, formed in September 1952 by 13 farm women near Deep River, Iowa. They elected officers, drew up bylaws, and decided on geographical boundaries to limit membership to local residents. Like clubs associated with the IFBFWC, the Friendly Neighbors Club held monthly meetings, followed parliamentary procedure, and collected 25-cent dues. The club provided service and support to members, particularly at times of birth, illness, or death. At its monthly all-day meetings, the women often helped the hostess with housework. They also held neighborhood events for entire families, with large Thanksgiving celebrations, welcome parties for new families, and going-away parties for those moving out of the area. The Friendly Neighbors Club performed some ser-

Rural Women's Day," "Mrs. Mavis Is Speaking at Rural Women's Meeting," and "Large Group Attends F. B. Women's Workshop," unattributed news clippings in Scrapbooks (1954-1956), Freedom Township Women's Club, Records, IWA.

28. Nell M. Forsyth, "Cedar Valley Club History" (June 1954), Cedar Valley Community Club Records, IWA; Meeting Minutes, 1942-1947, 1948-1959, ibid.; "History of the Cedar Valley Community Club, 75th Anniversary" (May 1995), ibid. 


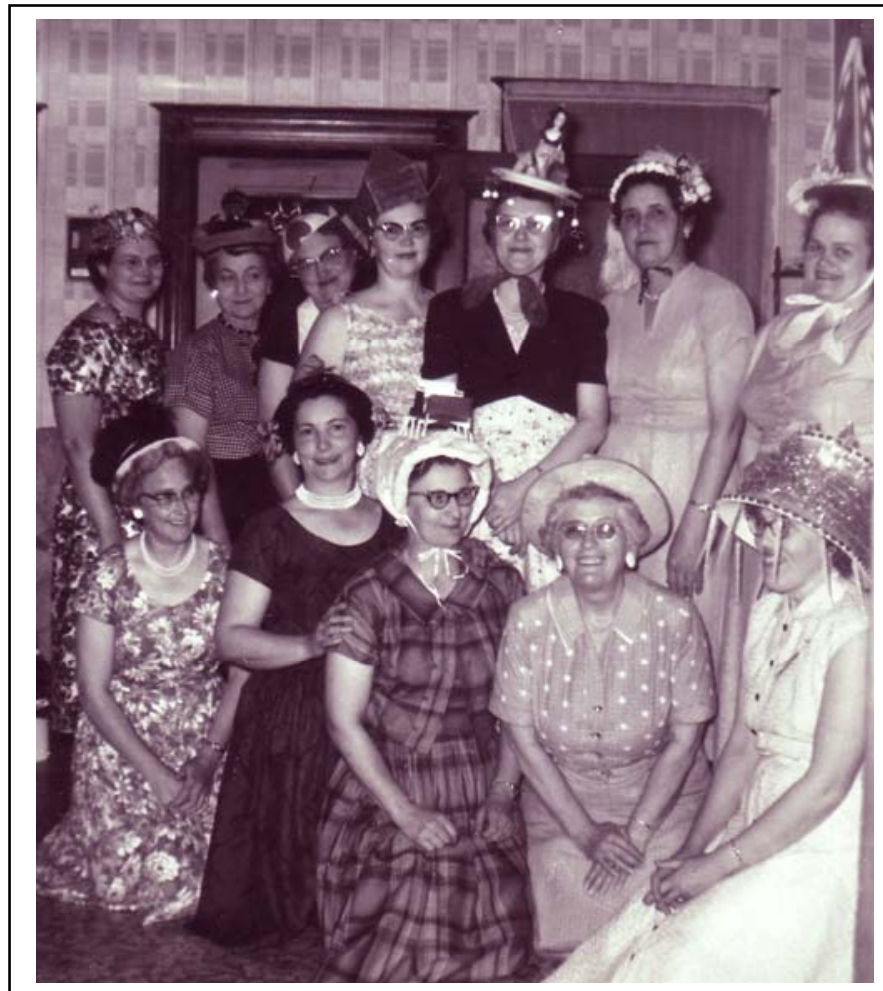

In May 1959 members of the Freedom Township Women's Club celebrated Mother's Day with a tea and a "Hat Parade." This reflects the humor and familiarity with which members of the Freedom Township Women's Club approached their activities. The invitation for the MotherDaughter Tea read: "We urge all ladies in the two to be present and bring as many daughters as you wish. If you have no daughter, perhaps you could borrow one for the evening." From Freedom Township Women's Club Records, Iowa Women's Archives.

vice projects but operated primarily as a social group. Not until January 1957 did the club include an educational component in its meetings. Members wrote to the federal government for information pertaining to civil defense and then used those materials to study the topic throughout the spring of that year. Yet educational activities were limited to the desires of the members, 
and the meeting minutes did not indicate that any members made education or politics the focus of the club. Although the Friendly Neighbors Club, and others like it, served essentially the same social purpose as clubs associated with the IFBFWC, there were clear distinctions. Informal clubs did not provide the same opportunities for community service, nor did they provide members with the rhetoric of leaders who wanted women to take a more public role in civic activities. ${ }^{29}$

THAT WOMEN in township Farm Bureau clubs selected different activities from those prescribed by state leaders was less a product of resistance and more a result of club members applying notions of social feminism in their own lives. Articles in the Iowa Farm Bureau Spokesman, speakers at Rural Women's Day, and materials produced through the IFBF and IFBFWC regularly affirmed this belief. Township clubs thrived throughout the 1950s and enjoyed growing or at least steady membership numbers. As local leaders took greater control over selecting and carrying out programs, they fulfilled the IFBFWC's mission to empower farm women and provide a setting in which adult education and women's activism could occur. By selecting activities applicable to their daily responsibilities and valued within their communities, local members believed that their clubs advanced standards of living in the countryside and made important contributions to the overall mission of the IFBF. In the immediate postwar period, between 1945 and the early 1960s, the IFBFWC's decision to focus on developing local leadership proved an effective strategy for addressing the changing needs of farm women.

Over a longer term, however, developing local leadership could not entirely hedge social and demographic changes that altered women's expectations and rural life. Throughout the 1960s and 1970s, membership in township women's clubs declined sharply because of rural depopulation and changing roles for women. The rhetoric of social feminisms used by the IFBFWC and township clubwomen was pervasive but restric-

29. Meeting Minutes, 1952-1953, Friendly Neighbors Club, Deep River, Iowa, Records, IWA; Scrapbook, 1952-1963, ibid. 
tive. By the mid-1960s, social feminisms continued to inform IFBFWC leaders but began to lose their resonance with farm women who enjoyed broader options for social, political, and wage-earning activities. According to political scientist Louise I. Carbert, domestic and maternal discourses only "justified women's political activity outside of private households in terms of their familial responsibilities" but exuded little authority "with policy analysts, administrators, or agronomists." For women with interests in agricultural production and policy, then, by the mid-1960s activism meant becoming involved in the IFBF alongside men either as "young marrieds" or on IFBF committees. Throughout the 1960s, the Mahaska County Farm Bureau Women's Committee strongly encouraged women to take on leadership roles within the county Farm Bureau. Far from serving in token positions, by 1969, 62 women served on nearly every Mahaska County Farm Bureau committee, including those that handled the budget, formulated policy resolutions for the state organization, and managed local affairs. Women also served on the committees for young members, legislative action, farm agreements, and health care. ${ }^{3}$

This is not to say that women abandoned county and township clubs in favor of the IFBF, only that they were no longer compelled to confine their political activities to separate, allfemale groups. As they found new outlets for activism and relied less on social feminisms to justify their participation, township women's clubs focused even more on home economics and social events. In 1971 Anita Crawford, a longtime member of the Westburg Township Women's Club and chair of the Buchanan County Farm Bureau Women's Committee, was selected to serve on the Buchanan County Farm Bureau Legislative Committee. She had served as legislative chairperson for her township club since 1965; having been a Farm Bureau member since the 1930s, she brought considerable experience to the position. At the time of her appointment, she received a letter from County Farm Bureau Chairperson Wayne L. Natvig regarding her new responsibilities for formulating county and state reso-

30. Carbert, Agrarian Feminism, 29; Josephine Van Zomeren, "Mahaska County Farm Bureau Women: A History" (December 1971), 112-17, Mahaska County Farm Bureau Women's Clubs Records, IWA. 
lutions. His letter made no reference to her gender. She was expected to read significant amounts of material pertaining to agricultural policy and travel to district meetings. Throughout her tenure as chairperson of the Legislative Committee, however, Crawford remained active in the kind of women's activities that were typical of township and county women's clubs. As chairperson of the Buchanan County Farm Bureau Women's Committee, she asked township leaders to hold programs about agricultural commodities and environmental hazards, including pesticides, nitrates, and clean-up methods. Crawford read widely, often wrote to legislators, and collected large amounts of information on marketing, property taxes, and pending legislation. She attended annual IFBFWC conferences and was very familiar with IFBFWC programs, but she still spent much of her time as county chairperson planning social events such as Rural Women's Day and a Rural-Urban women's tea. ${ }^{31}$

Membership rolls of clubs that remained intact throughout this period, including the Highland Do-Better Club in O'Brien County and Sharon Township Women's Club in Johnson County, illustrate that as older members left the club, younger women interested in homemaking, crafts, and learning the home production skills of the previous generation often replaced them. Yet the number of young women was not large enough to replace those older members who had left, and like township clubwomen of the immediate postwar period, few of these younger women sought outlets for becoming agricultural activists. Many worked off the farm or were involved on other IFBF committees or in other farm organizations. They primarily desired a group where they could develop and celebrate their identities as farm wives. Overall, clubs affiliated with general farm organizations, such as the Farm Bureau, remained popular among rural residents across the United States. A 1980 survey of American farm women revealed that 74 percent were involved in some type of farm or community organization, and 41 percent of those were involved in a general farm organization such as the Farm Bureau or a women's auxiliary of a general farm

31. Wayne L. Natvig to Anita Crawford, 12/3/1970, and Art Kitner to Anita Crawford, 2/6/1967, Anita Crawford Papers, IWA; IFBFWC Annual Conference Programs, 1969-1974, ibid.; Meeting Notes, 1969-1971, ibid. 
organization. The survey revealed that age, farm employment, and political affiliation proved negligible in identifying who participated in farm organizations; the extent of an individual woman's involvement depended primarily on her connection to the family farm, whether she shared ownership in the farming operation, her level of education, and the availability of economic resources. For younger women then, participating in a Farm Bureau women's club was more likely an indicator of social status and leisure time than it had been for the previous generation. $^{32}$

More so than changing ideologies, depopulation proved to be a key factor in the decline of township women's clubs. Political scientist Louise Carbert found that by the late 1960s declining membership in Canadian farm women's organizations was "attributable to the depopulation of farming and rural communities" rather than continued use of social feminism or outdated agendas. The IFBFWC tried to keep Farm Bureau women in step with changing times by addressing issues such as women's health and by providing material on economic change, marketing, and agriculture that encouraged women to become more involved with the business of farming. As the rural population declined and aged, recruiting new members became difficult because there were simply fewer women who could join. In sparsely populated Palo Alto County, between 1950 and 1970, the total population fell from 15,891 to 13,289 , while the number of farms declined from 1,808 to 1,186, with much of the depopulation occurring after 1960. Those who remained tended to be older, established farmers. Citing these conditions, the increasing age of its members, and its inability to attract new members, the Freedom Township Women's Club decreased its involvement with the county Farm Bureau and, after 1962, no longer participated in Rural Women's Day. It remained active by maintaining the Freedom Township Hall, purchased by the club in 1953, and

32. Membership Rolls, Highland Do-Better Club, 1960-1984, Highland DoBetter Club Records, IWA; Membership Rolls, 1961, 1970, 1980, 1983-1984, Sharon Township Women's Club Records, IWA; Jenny Barker-Devine, “'Our Cherished Ideals': Rural Women, Activism, and Identity in the Midwest, 19501990" (Ph.D. diss., Iowa State University, 2008), 186-90; Rachel Ann Rosenfeld, Farm Women: Work, Farm, and Family in the United States (Chapel Hill, NC, 1985), 198-215. 
continued to invite speakers from the local area, complete craft projects, and even assembled "ditty bags" for servicemen in Vietnam. Yet the club's meetings lost much of the formality that characterized club functions prior to 1960 and by the early 1970s more closely resembled gatherings for old friends. The women of Freedom Township were not alone, as other clubs across the state made similar decisions over the next three decades. ${ }^{33}$

AFTER 1945, members of both the IFBFWC and township Farm Bureau women's clubs sought to refine the roles of women as farm wives and as members of a greater organization. In order to cope with changes in the countryside, such as depopulation, the introduction of new agricultural and household technologies, and the separation of the IFBF and the Extension Service, the IFBFWC and members of township clubs agreed that greater local control allowed women to develop leadership skills and educational programs that best suited their needs and interests. Since the 1920s, the IFBFWC had politicized farm women's work and encouraged Iowa farm women to work for higher standards of living by participating in local clubs. State leaders repeatedly identified township clubs as the foundation of the state organization, and by the 1950s seasoned clubwomen demonstrated that they had received this message. At the township and county level they easily conducted meetings and carried out projects that they believed to be within the mission of the IFBF without direct assistance from home demonstration agents or IFBFWC leaders.

In the immediate postwar period, the IFBFWC insisted that Iowa farm women devote meetings to political and agricultural issues at the national and international levels, but the great majority of members in local clubs did not share that enthusiasm. Township clubwomen's preferences for social and practical ac-

33. Carbert, Agrarian Feminism, 17; Barker-Devine, "Our Cherished Ideals," 186-88; Richard L. Forstall, ed., "Iowa," Population of Counties by Decennial Census: 1900 to 1990 (Washington, DC, 1995), accessed 7/6/2009 at www.census.gov/population/cencounts/ia190090.txt; 51st Annual Iowa Year Book of Agriculture (Des Moines, 1950), 549; Iowa Book of Agriculture, Fifth Biennial Report (Des Moines, 1961), 330; Iowa Book of Agriculture, Tenth Biennial Report (Des Moines, 1971), 345; Scrapbooks, 1969-1970, Freedom Township Women's Club Records, IWA. 
tivities reveal that they critically interpreted the rhetoric and plans of state leaders and practiced selectivity when creating unique projects and annual programs. Social feminisms, shaped by domestic and maternal discourses, resonated with farm women in the postwar period because, although they understood the vital nature of their work for their families, their farms, and their communities, farm women also lived with the reality that women's voices carried little authority in predominately male agricultural organizations and political circles. And although the IFBFWC assured them that political and international concerns could exist within the domestic realm, most women did not find these issues to be particularly relevant to their daily lives.

State leaders and local members may have disagreed on appropriate programming for club meetings, but for a time, between 1945 and the early 1960s, the development of local leadership appeared to foster the growth of county and township women's clubs. Offering township clubs greater freedom to operate independently enabled the IFBFWC to successfully weather the loss of the Extension Service, which had been so instrumental in supporting women's activities, and to develop new programs for women of varied ages. Ultimately, this growth proved unsustainable, and membership numbers declined throughout the 1960s and 1970s. That was not because of the programs selected by township clubs, nor did it occur as part of a greater rebellion against the IFBF, the IFBFWC, or the social feminisms these organizations espoused. Rather, it was a result of rural depopulation and the emergence of new political outlets for women. The postwar period was a pivotal moment in rural women's activism in Iowa, as women took greater ownership of their clubs and selected activities that they believed would attract the most members. They did not necessarily find political outlets in Farm Bureau clubs, but they did find support, information, and friendships that enabled them to embrace higher standards of living and new technologies while keeping some semblance of the neighborhoods and informal networks that were quickly disappearing in an era of modernization. 